\title{
O magicznym czarze pewnej głoski
}

\begin{abstract}
The correct pronunciation of [č ] sound is one of the most difficult problems in articulation that arises in the last period of speech development among children. Be it nursery rhymes or other rhymed texts, the orthophonic games and activities supposed to evoke this sound and develop articulation include the words of fairy-tale origins; not only do they contain and exercise the aforementioned sound, but also they point to the theme that is liked and highly regarded by children. In addition to the brief analysis of this issue, the chapter presents some of the games and activities that might facilitate acquisition and processing of the correct pronunciation of the aforementioned "magical" sound.
\end{abstract}

Keywords: sound [č], orthophonic games and activities, child, paidia

Od momentu narodzin funkcjonujemy w rzeczywistości językowej — oswajamy ją przez poznawanie i czynną partycypację. Rola mowy ${ }^{1}$, stanowiącej naturalną potrzebę człowieka, w tym podstawę jego rozwoju umysłowego, procesów poznawczych i akulturacji, jest nie do przecenienia. Deficyty mowy siłą rzeczy skutkują problemami rozwojowymi i/lub trudnościami utrzymania odpowiedniego poziomu rozmaitych czynności związanych z takimi sprawnościami, jak rozumienie, czytanie i pisanie, które wespół z mówieniem determinują właściwe funkcjonowanie jednostki. Jak podkreśla Kinga Kozłowska, dziecięce niedobory kompetencji językowych „rzutują na sferę intelektualną, emocjonalną i społeczną. Są czynnikiem rodzącym agresję, przemoc, niedostosowanie społeczne i poczucie niższej wartości" (Kozłowska, 2004, s. 11).

Na każdym etapie rozwoju mowy dziecka należy je stymulować i zachęcać do działania przez różnorodne zabawy doskonalące jego słuch mowny, w szczególności słuch fonemowy², pracę artykulatorów (głównie warg, żuchwy, języka,

1 „Mowę” rozumiem jako „zespół czynności, jakie przy udziale języka wykonuje człowiek, poznając świat i przekazując jego interpretację innym uczestnikom życia społecznego" (Grabias, 2012, s. 15).

${ }^{2}$ Słuch mowny, związany z rozwojem percepcji słuchowej, dzielony jest na fonemowy, fonetyczny i prozodyczny (Skorek, 2001, s. 82). Pierwszy z nich polega na prawidłowym odróżnianiu 
podniebienia miękkiego) i dykcję. Prawidłowa wymowa jest sztuką trudną, której opanowanie zwykle następuje około piątego-szóstego roku życia, mimo to „często dzieci w przedszkolach i klasach edukacji wczesnoszkolnej mówią niedbale, niewyraźnie, krzykliwie, cicho, oddychają nieprawidłowo, na przykład ustami, mówią na wdechu, połykają końcówki” (Malkiewicz, 2007, s. 3).

Do jednego z najtrudniejszych problemów artykulacyjnych końcowego okresu kształtowania się poprawnej mowy (około piątego roku życia) należy opano-

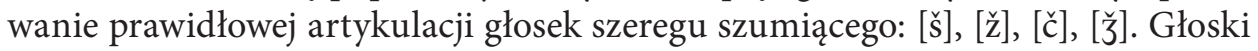
te bywają seplenione - zastępowane innym szeregiem spółgłosek, syczącym: [s], [z], [c], [3] lub ciszącym [ś], [ź], [ć], [ź] (Malkiewicz, 2007, s. 9-10, 12).

Prawidłowa realizacja afrykatów jest dwufazowa, w początkowym momencie artykulacji czubek języka dotyka wałka dziąsłowego, następnie zwarcie kończące się eksplozją przechodzi w szczelinę, w przypadku [č] zęby są zbliżone, wargi lekko zaokrąglone, wysunięte do przodu (Ostaszewska, Tambor, 2004, s. 37-38; Sarosiek, 2015, s. 55). Omawiana głoska jest bezdźwięczna - wydychane powietrze, by dostać się do nasady, swobodnie przechodzi między rozsuniętymi strunami głosowymi ${ }^{3}$. Głoski zwarto-szczelinowe ze względu na dwuetapową artykulację są chwilowe, próba przedłużania ich wymowy prowadzi do frykatywności (np. [č przechodzi $\mathrm{w}[\check{s}]$ ).

Efektywność działań o charakterze logopedycznym zależy od skali komplikacji wady, indywidualnych cech dziecka, regularności ćwiczeń dotyczącej zarówno spotkań z nauczycielem i/lub logopedą, jak i wykonywania zadań w domu ${ }^{4}$ (Polczyk, 2015, s. 406). Podstawowe wytyczne terapii przedstawiają m.in. Grażyna Jarzębiowska i Olga Pelc-Pękała (2003) czy Genowefa Demel (2008). Na początku należy odpowiednio przygotować artykulatory. Poprawnie wywołaną głoskę powinno się ćwiczyć w izolacji, następnie w logotomach, wyrazach i krótkich konstrukcjach wyrazowych, wreszcie na dłuższych wypowiedzeniach (warto w tym celu posłużyć się również tekstami literackimi). Dzięki gradacyjnemu

najmniejszych, nieposiadających znaczenia, elementów składowych wyrazu (fonemów), wyodrębnianych zwykle na zasadzie opozycji (np. dźwięczność — bezdźwięczność). „Przy niedokształceniu słuchu fonemowego dziecko może mieć problemy ze zrozumieniem poleceń słownych, może zniekształcać wyrazy podczas pisania z pamięci lub ze słuchu. Często dzieci z zaburzeniami słuchu fonemowego nie rozróżniają głosek dźwięcznych i bezdźwięcznych, ustnych i nosowych oraz zamieniają głoski dwóch szeregów: szumiącego i syczącego" (Bogdańska, Olszewska, 2008, s. 3). Dobrze wykształcony słuch fonetyczny z kolei pozwala na oddzielanie tych głosek (różnych realizacji fonemów), które wymawiane są poprawnie, od artykułowanych wadliwie, dostrzeganie niuansów, np. [r] uwularnego (francuskiego) od przedniojęzykowego. Rozwinięty słuch prozodyczny zaś pozwala na odróżnienie takich cech, jak: akcent, melodia, rytm, intonacja czy głośność.

${ }^{3}$ Bezdźwięczność jest jedyną cechą odróżniającą [č] od [క̌].

${ }^{4}$ Rola rodziców jest nieoceniona nie tylko w trakcie trwania terapii, lecz również przed nią. Dziecko nie zdaje sobie sprawy z tego, że mówi niepoprawnie, dlatego tak ważne jest działanie najbliższych opiekunów, którzy są pierwszymi korektorami, starającymi się, by mowa pociechy rozwiała się prawidłowo. 
ujęciu (od ćwiczeń łatwiejszych po coraz bardziej skomplikowane, zawsze dostosowanych do możliwości dziecka) podopieczny czuje się dowartościowany - co z kolei sprzyja świadomemu i chętnemu uczestnictwu w zajęciach.

Program logopedyczny, by dobrze spełniał swą funkcję, musi cechować podejście podmiotowe - rozwój osobniczy przebiega indywidualnie, zależy m.in. od organizmu i warunków stwarzanych w najbliższym otoczeniu, w związku z tym „należy starannie dopasować każde zadanie do możliwości i potrzeb dziecka, aby wypracowany efekt był jak najlepszy i jak najbardziej trwały" (Minczakiewicz, 2010, s. 24). Takie ujęcie zgodne jest z modelem pajdocentrycznym stawiającym dziecko i jego świat w centrum społeczeństwa i kultury (Ostasz, 2008, s. 12). W pajdocentrycznych tekstach literackich świat przedstawiony ujmuje się z pozycji dziecka, jego podmiotowego punktu widzenia i sposobu rozumowania ${ }^{5}$.

Ćwiczenia usprawniające motorykę i artykulację mogą być zadaniowe i/lub zabawowe. Zabawa ${ }^{6}$, będąc podstawą kultury dziecka, stanowi jego naturalną formę aktywności, przyczyniającą się do rozwoju psychicznego i fizycznego (Ostasz, 2008, s. 19). Daje dziecku poczucie wolności (Cieślikowski, 1985). O fortunności ludycznego charakteru ćwiczeń ortofonicznych świadczy również to, iż „W zabawie dzieci rozluźniają się i cieszą z tego, co robią. Ćwiczenia oddziałują na psychikę dzieci, powodują odprężenie umysłowe, budzą wiarę we własne siły, dają lepsze samopoczucie i ułatwiają kontakt z otoczeniem" (Malkiewicz, 2007, s. 18). Taki typ aktywności stanowi nieoceniony bodziec do pracy. W formie zabaw można trenować wszystkie najważniejsze składowe procesu prawidłowego mówienia. Wśród celów zabaw ortofonicznych wymienia się: naukę prawidłowego oddychania, usprawniania artykulatorów, percepcji słuchowej, koordynacji słuchowo-ruchowej i poczucia rytmu, stymulowanie do rozwoju umiejętności językowych, wzbogacania słownictwa, zachęcania do twórczej aktywności słownej, budowania dłuższych, poprawnych językowo wypowiedzi, trening koncentracji uwagi, rozwijanie pamięci i wyobraźni (Malkiewicz, 2007, s. 15). We wszystkich zabawach powinna aktywnie uczestniczyć osoba je koordynująca (rodzic, nauczyciel, logopeda): wyjaśniająca i pokazująca wykonanie zadania, stanowiąca dla dziecka wzór do naśladowania.

Dzięki wyobraźni świat dziecka, jego sposób postrzegania i przeżywania, rozpięty jest między rzeczywistością a fikcją. Twórcze myślenie związane z fantazjowaniem zdaje się "głównym generatorem niedościgłych pomysłów, pozwalających na kreowanie dotąd nieznanych mu scenariuszy działań, wokół których

${ }^{5}$ O perspektywie i punkcie widzenia dziecięcego odbiorcy literatury pisała m.in. Jolanta Ługowska (2004).

${ }^{6}$ Johan Huizinga zabawą określa „dobrowolną czynność lub zajęcie, dokonywane w pewnych ustalonych granicach czasu i przestrzeni według dowolnie przyjętych [...] reguł, jest celem samym w sobie, towarzyszy jej zaś uczucie napięcia i radość, i świadomość »odmienności« od »zwyczajnego życia«". Huizinga, 1985, s. 48-49. 
narasta jego ciekawość” (Minczakiewicz, 2010, s. 9). Wykorzystanie tak lubianych przez dzieci - i cenionych przez dorosłych (Bettelheim, 1985) - motywów baśniowych, toposów odwołujących się do magiczności widoczne jest zarówno w prostych zabawach ortofonicznych, jak i tekstach literackich służących potrzebom działań logopedycznych. Jak zauważa Maria Ostasz, „Poeci chętnie sięgają również do zabawowych zachowań dzieci polegających na tworzeniu rzeczywistości »na niby« i zarazem odkrywaniu w realnym świecie czarodziejskości i magii. Operowanie formułami posiadającymi funkcję magiczną, zaczerpniętymi z języka dzieci, pozwala stworzyć świat zgodny z ich wolą i imaginacją" (Ostasz, 2008, s. 27). Siłą rzeczy ze wspomnianych względów często przeznaczone dla dziecięcego odbiorcy zabawy ortoepiczne, w tym teksty wierszowane, służące wywołaniu głoski [と̌] oraz podnoszące jej sprawność artykulacyjną, uwzględniają słowa związane z leksyką baśniową - zawierając bowiem ćwiczoną głoskę (por. np. czarodziej, czarnoksiężnik, magiczny, księżniczka, róż$d \dot{z} k a^{7}$, miecz, królewicz), odwołują się do lubianej i cenionej przez dzieci tematyki.

W związku z wykorzystywaniem poezji w programie logopedycznym dzieci konieczne wydaje się skrótowe przybliżenie teorii wiersza pajdialnego ${ }^{8}$. Na podstawie klasyfikacji Rogera Caillois (1973) wyróżnia się tzw. regułę pajdialną (Ostasz, 2008; Ostasz, Michalik, 2016) stanowiącą matrycę kompozycyjną utworów należących do poezji (czy szerzej - literatury) dziecięcej ${ }^{9}$. Współtworzą ją następujące typy: mimicry (mimetyzm świata przedstawionego, inspiracja do naśladowania ról i zjawisk), alea (nakłanianie obrazem świata przedstawionego, magiczna moc form językowych zachęcająca do działania), ilinx (skłanianie do repetycji, wielokrotne powtarzanie wybranych przejawów mimicry, paralelizmy motywów itd.), agon (współzawodnictwo w odgrywaniu lub wypełnianiu ról, kontrastowość bohaterów itd. ${ }^{10}$. „Im bardziej dostrzegalna i czytelniejsza ta reguła w wierszu, tym utwór jest doskonalszy, tym bardziej satysfakcjonuje małego odbiorcę, ponieważ bawi go i jednocześnie uczy" - przekonuje Maria Ostasz (2008, s. 11). W poezji dziecięcej widoczne są zatem wzajemne przenikanie i uzupełnianie się, opalizowanie pierwiastków zabawy, estetyki i wychowania (w tym perswazji), zwykle z przewagą tego pierwszego.

${ }^{7}$ Należy pamiętać o różnicach między wymową a pisownią: różdżka [ruščka].

${ }^{8} \mathrm{~W}$ załączonym scenariuszu — propozycji zabaw usprawniających artykulację głoski [č] — są dwa przykłady logopedycznych wierszy pajdialnych.

${ }_{9}$ Nie wszystkie wiersze skierowane do dzieci muszą jednak odznaczać się pajdialną jakością. Ostasz, 2008, s. 64-65.

${ }^{10}$ Układ typów w danym dziele (ich kontaminacje, dominacja jednego z nich lub niedobory) determinuje podział na rodzaje paidii: a) typową i pełną, b) ukierunkowaną na zniewalanie (alea), c) ukierunkowaną na powtarzanie (ilinx), d) ukierunkowaną na rywalizację (agon), e) niepełną (brak jednego z typów), f) ułomną (brak dwóch typów), g) minimalną (brak trzech typów). Ostasz, 2008, s. 66-105; Ostasz, Michalik, 2016, s. 11-12. 
$\mathrm{W}$ terapii wykorzystanie logopedycznego wiersza pajdialnego jest pożyteczne: „[... [ w warstwie formalnej lub/i treściowej może nastąpić proces diagnozowania czynności poznawczych człowieka (sprawności leksykalnej, semantycznej i narracyjnej), przekazu wiedzy i realizacji intencji (czynności mówienia, sprawności dialogowej i językowej sprawności społecznej), programowania terapii logopedycznej i jej prowadzenia w zakresie budowania kompetencji lingwistycznej, usprawniania realizacji różnych poziomów systemu komunikacji oraz - ewentualnie - odbudowania kompetencji lingwistycznej" (Ostasz, Michalik, 2016, s. 13-14). Obcowanie z tego typu tekstami często odbywa się przy pomocy dorosłego pośrednika dziecięcej lektury. Podopieczny wchodzi w rolę słuchacza, co wspomaga jego wyobraźnię i stymuluje rozwój mowy. Utwory tego typu prowokują do mnemotechnicznych zabaw artykulacyjnych ${ }^{11}$.

Problem z prawidłową jakością artykułowanych wypowiedzi staje się coraz powszechniejszy, potwierdza to m.in. lawinowo odnotowywany wzrost wad anatomicznych młodego pokolenia (wynikający np. z rezygnacji $z$ naturalnego sposobu karmienia, ze spożywania przez dzieci miksowanych pokarmów, z nadużywania smoczków, kubków niekapków), przekształceń modelu rozwoju psychoruchowego, chorób, w tym nasilających się tendencji do alergii (Sambor, 2014, s. 257) ${ }^{12}$. Wielu wymienionym przypadkom można było zapobiec: im prędzej zdiagnozuje się i wdroży ćwiczenia (w tym zabawy) rozwijające wszelkie kompetencje językowe, tym szybciej widoczne będą efekty. Ćwiczenia należy wykonywać systematycznie - bez tego „każda, nawet najcięższa, praca przyniesie niewymierne rezultaty" (Minczakiewicz, 2010, s. 24). Muszą być realizowane dokładnie, zgodnie z zaleceniami (by polepszyć artykulację, a nie utrwalić wadliwą formę lub nie pogorszyć dotychczasowej artykulacji).

W aneksie opracowania zamieszczono przykładowy zestaw ćwiczeń działań o charakterze ortoepicznym, wspomagających przyswajanie i mechanizację prawidłowej artykulacji „magicznej” głoski [č] oraz zapisu digrafemu $c z$, a także wspierających rozwijanie słownictwa, czasem pisania, jak również spostrzegawczości i pamięci. Zadania skierowane są do dzieci mających problem z wymową omawianej głoski oraz do rodziców, opiekunów (ewentualnie nauczycieli przedszkoli, nauczania wczesnoszkolnego czy przyszłych logopedów) - przewodników po poszczególnych zadaniach. Oferta zabaw ma różny stopień trudności,

${ }^{11}$ Za autorami Logopedycznego wiersza pajdialnego można przyjąć, że „głównym przejawem paidii $\mathrm{w}$ takich tekstach jest ilinx, ponieważ dominuje w nich wielokrotne powtarzanie ćwiczeń językowych, wywołane magią wierszowego słowa (alea) naśladujących zainspirowane działanie ( $m i-$ micry), zmierzające do wzorcowej doskonałości (agon)”. Ostasz, Michalik, 2016, s. 52.

${ }^{12}$ Następstwem tej sytuacji jest m.in. niesłabnąca popularność studiów kształcących specjalistów w zakresie logopedii. 
przeznaczona jest dla podopiecznych w różnym wieku, o odmiennych możliwościach i potrzebach. Przedstawione propozycje mogą stanowić uzupełnienie terapii logopedycznej, jak również inspirację do innych pomysłów. Całość spięta jest klamrą tematyczną często wykorzystywanego motywu czarodziejskości, do czego głoska [č] sama w sobie zachęca ${ }^{13}$. Ćwiczonej głosce towarzyszy bohaterka zabaw - czarodziejka Aneczka ${ }^{14}$.

Potencjał, jaki tkwi w dziecięcych zabawach ortofonicznych, w tym w rymowankach i wierszach logopedycznych (utworach zarówno stworzonych z tą intencją, jak i tych, które wtórnie posłużyły do celów terapeutycznych), jest ogromny - warty wdrożenia również w nauce wymowy języka polskiego jako obcego/ drugiego (por. Wacławek, 2007; Wacławek, 2014; Wacławek, Wtorkowska, 2017) ${ }^{15}$. Jest to jednak temat do dalszych badań.

\section{Aneks}

\section{Propozycje zabaw ortoepicznych}

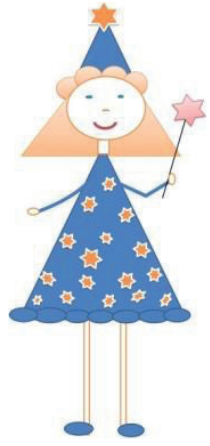

Cześć! Jestem Aneczka, jak widzisz, jestem czarodziejką. Mam magiczną różdżkę, która potrafi zamienić się na przykład w słomkę (do picia soków czereśniowych, które uwielbiam). Masz może słomkę? Pobawimy się razem w dmuchanie i bulgotanie?

Potrzebujemy kubeczek z wodą, a w nim słomkę. Kubeczek będzie naszym czarodziejskim kociołkiem. By dobrze przygotować w nim wywar - trzeba go w magiczny sposób przyrządzić (w tym podgrzewać i ostudzać). Zaczynamy?

Nabieramy powietrze przez nos, a potem wydmuchujemy przez słomkę na dwa sposoby:

- nie dotykając powierzchni wody, delikatnie dmuchamy tak, aby powstała dziurka;

- wkładamy słomkę do kubka z wodą i dmuchamy tak, aby trochę, potem mocniej i bardzo mocno bulgotała („ogrzewanie”, „gotowanie”, „kipienie”).

Teraz dmuchamy na wodę bez użycia słomki, na zmianę: długo — krótko — najdłużej (ostateczne „schłodzenie”).

Każdą z tych zabaw trzeba powtórzyć kilkakrotnie. Podobnie będzie z następnymi.

${ }^{13}$ Ze względu na nieczytelność dla dzieci zapisu fonetycznego - [č] (brak świadomości różnicy między głoską a literą) - będę używać graficznego oznaczenia $c z$ bez względu na to, czy ćwiczenie ma charakter stricte artykulacyjny czy ortoepiczny. Jestem świadoma przyjętego uproszczenia (będącego normą w materiałach o charakterze logopedycznym skierowanych do nieprofesjonalistów - dzieci i dorosłych).

${ }^{14}$ Pomysł wykorzystania bohatera-przewodnika jest zaczerpnięty z serii Logopedia na Wesoło wydawnictwa Impuls (Sarosiek, 2015; Postołowicz, 2017). Niektóre ćwiczenia były również inspirowane tym źródłem.

${ }^{15}$ Należy jednak baczyć, by tak dobierać ćwiczenia, zabawy ortoepiczne (w tym teksty literackie), aby w razie nauki dorosłych nie dopuszczać do ich infantylizacji. 
Weź do buzi trochę wody z kubeczka (ale jej nie połykaj): teraz wodę ruchem policzków i ust przesuwaj z jednej strony buzi na drugą (z prawej na lewą i z lewej na prawą), zrób to kilka razy, a następnie odchyl głowę do tyłu i przez chwilę gulgotaj. Teraz wodę trzeba wypluć (do zlewu, ewentualnie kubeczka). Już nie będzie nam potrzebna.

Moja magiczna różdżka wyczarowała konika, który kląska: otwórz usta i naśladuj jadącego źrebaka (język przykleja się do podniebienia i odkleja od niego): konik najpierw bardzo wolno spaceruje, a następnie jedzie szybciej, potem galopuje (kolejno powolne, szybsze i bardzo szybkie kląskanie).

Konik bardzo się zmęczył i musimy się z nim pożegnać, wyślij mu ogromne całusy (ułóż usta do pocałunku i mocno je rozszerz, cmoknij — ruch jest podobny do bezdźwięcznego wymawiania $u-a)$.

A teraz czas na czarodziejską „pieczątkę”: otwórz buzię, językiem naciśnij na górne dziąsło w taki sposób, jakbyś chciał/chciała odcisnąć na nim pieczątkę. Zrób to kilka razy.

I. Oto znaki rozpoznawcze czarodziejki Aneczki. Czy je znasz? Przeczytaj (powtórz) je kilka razy:

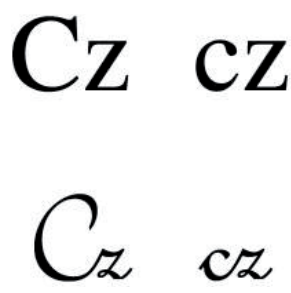

II. Cz jest magiczne - w miarę trwania jego wymowy dźwięk się zmienia. Możesz to sprawdzić! Długo i powoli wymawiaj cz. Jaki dźwięk (jaką głoskę) później słyszysz? Tak, to $s z$.

III. Czarodziejka Aneczka ma tęczowe korale. Pokoloruj każdy koralik na wybrany (inny) kolor i powtarzaj sylaby - to zaklęcie, które przynosi szczęście.

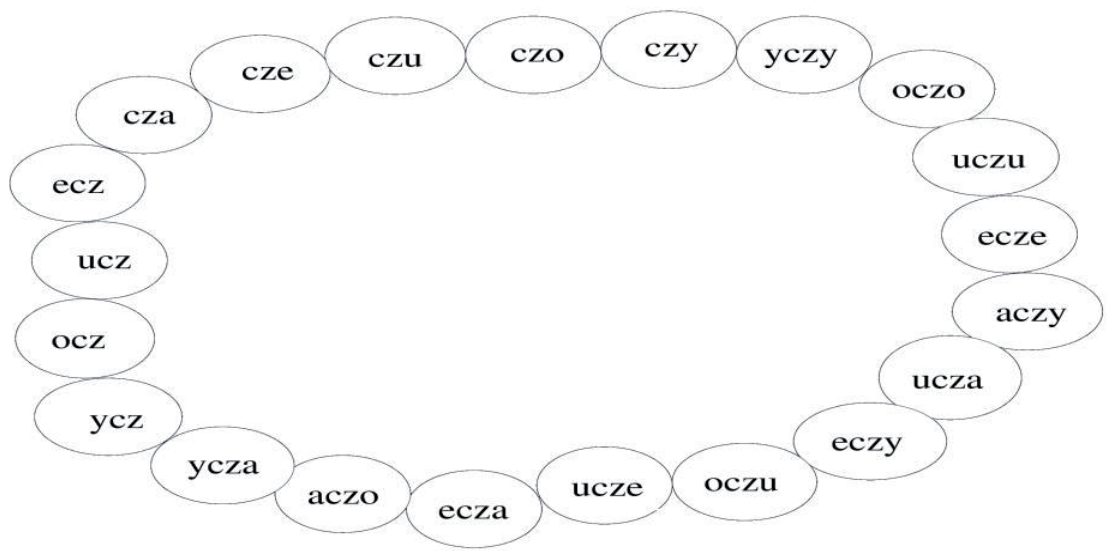


IV. Zobacz, co kupił wujek Aneczki - czarodziej Mieczysław.

\section{Czarodziej Mieczysław kupił}

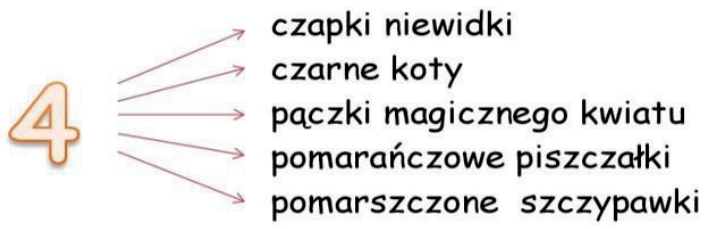

Powtórz całym zdaniem: Czarodziej Mieczysław kupił cztery czapki niewidki... Po co to kupił? Co jeszcze mógł kupić czarodziej?

V. Pomóż czarodziejce dojść do pieczary (jaskini).
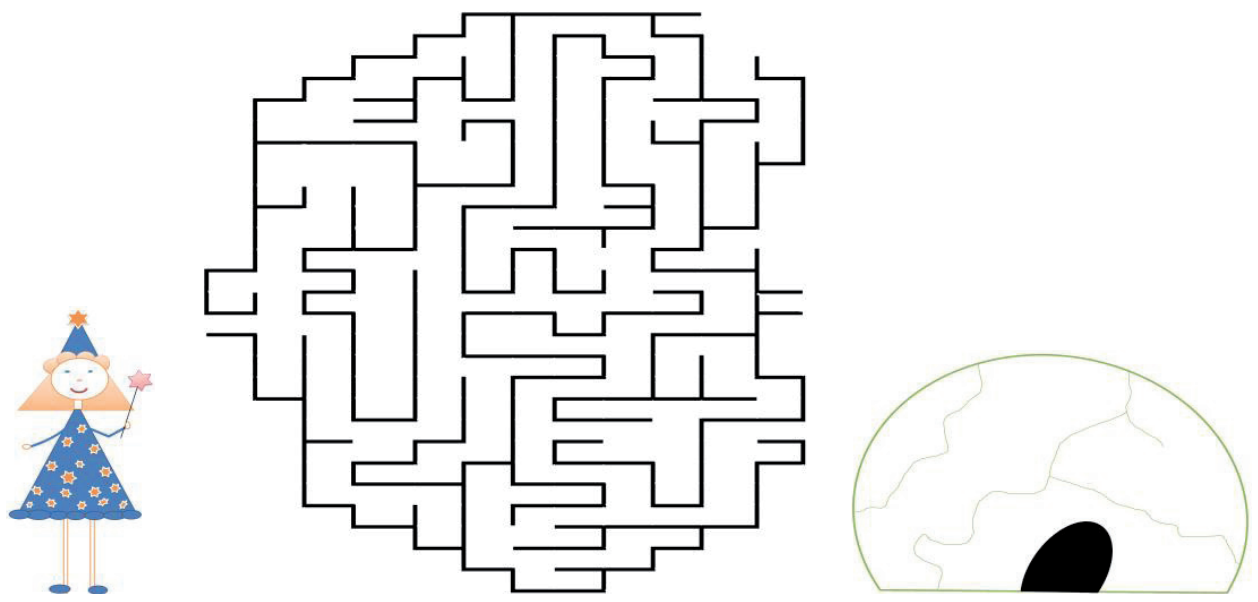

VI. Co Aneczka ma w czarodziejskim worku? Przeczytaj (lub powtórz) te wyrazy.

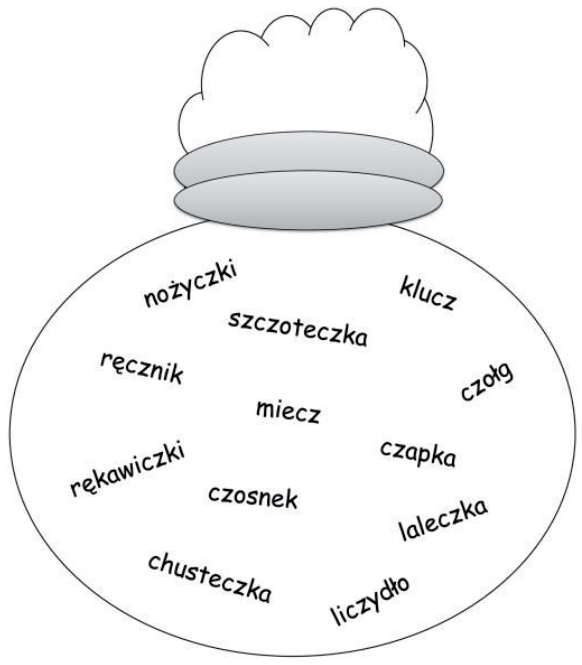

Jakie znasz jeszcze słowa $\mathrm{z} c z$ ?

Czy masz $\mathrm{w}$ domu rzeczy $\mathrm{z}$ worka (i ewentualnie wymienione przez ciebie inne przedmioty zawierające $c z$ )? Przynieś je i pobaw się z rodzicem lub opiekunem w zgadywanie. Włóż rzeczy do własnego czarodziejskiego worka (własnej czarodziejskiej torby). Wylosuj przedmiot, powiedz, co to jest - dotykając tego, ale go nie widząc. 
VII. Aneczce rozsypały się karteczki z różnymi słowami. Przeczytaj (powtórz) je. Które $z$ nich mają $c$, a które $c z$ ?

Czerwoną kredką zakreśl kółeczko wokół cz, z kolei niebieską kredką zaznacz $c$.
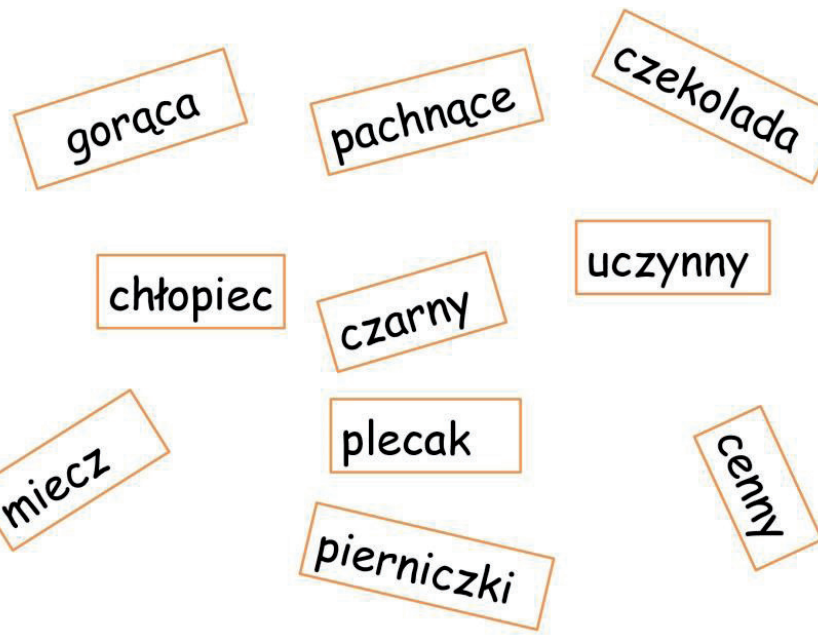

\section{uczynny}
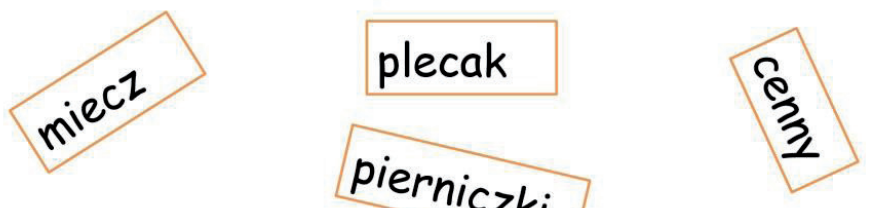

Zieloną kredką połącz wyrazy w pary (tak, aby stanowiły logiczną całość).

VIII. Przeczytaj tekst (lub go posłuchaj), a następnie rozwiąż krzyżówkę (są tam trudniejsze słówka $\mathrm{z}$ tekstu). Jakie jest hasło?

Czarnooki czarnoksiężnik Czesław w czerwonym płaszczu czyta w czytelni o czaplach i czereśniach z Czech. Czarujący to człowiek, czyż nie? Na jego czasomierz w czwartki czyhał chłopczyna z czarną czupryną. Często czekał na niego w deszczu, ale ostatecznie czmychnął w puszczę.

6.

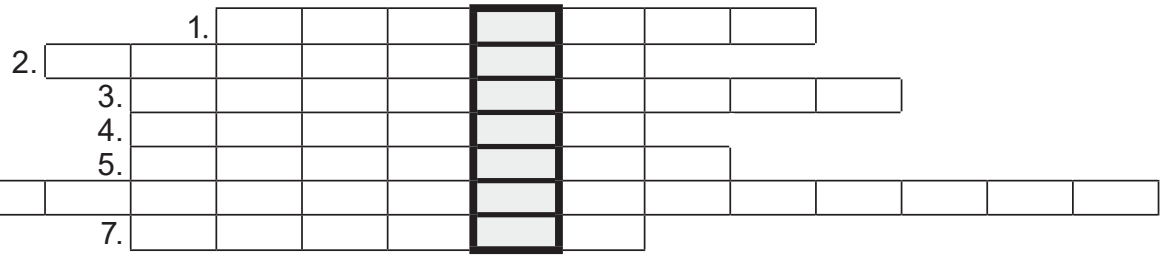

1. Mierzy czas, inaczej stoper.

2. W miarę krótkie i bardzo gęste włosy.

3. Są słodkie i czerwone, o nich czytał czarnoksiężnik.

4. Często pada jesienią lub na wiosnę.

5. To ubranie czarnoksiężnika ma czerwony kolor.

6. Człowiek zajmujący się czarami, jest nim czarnooki Czesław.

7. Czekać w ukryciu (by zaatakować).

Jakie jest hasło krzyżówki? Kto to jest? 
IX. Oto wierszyk o czarodziejskim królewiczu - przyjacielu Aneczki.

Przeczytaj (posłuchaj) go.

Czary - mary ${ }^{16}$

Czapla czarną ma czuprynę, kaczka wpadła w pajęczynę.

Puchacz włożył rękawiczki, pączki wpadły do doniczki.

Kaczor loczki ma czerwone, cztery rączki i ogonek.

Biegacz wpadł na metę czwarty.

Kto tu robi takie żarty?

To królewicz January -

on uczynił takie czary.

Czarodziejkę ma pałeczkę

i namieszał tu troszeczkę.

Krupa, 2008, s. 9

Opowiedz własnymi słowami, co dziwnego się działo i kto to spowodował.

$\mathrm{X}$. Ten wiersz opowiada z kolei o znajomej czarodziejki Aneczki — czarnej musze. Przeczytaj (posłuchaj) go.

Czarna magia

Czarna mucha w czarnym lesie czarnej smoły kocioł niesie.

Czarną nocą czarne czary będę działać, nie do wiary. Kiedy doszła na polanę, Powiedziała: tu zostanę. Rozpaliła więc ognisko: rozbłysnęło wokół wszystko. Leje w kocioł czarną wodę to na młodość i urodę.

Czarnej wrony wrzuca pióra, czarnej sierści i kocura.

Czarny węgiel, czarny cień żeby mieć udany dzień.

Czarny guzik, czarna nić żeby przestać ciągle tyć. Czarny kret i czarne błoto, by diamenty mieć i złoto. Czarny krawat da do tego, żeby męża mieć pięknego.

16 Wszystkie pogrubienia pochodzą od autorki wiersza. 
Jeszcze wrzuci czarną szmatkę na paskudną swą sąsiadkę.

I czarnego garść humoru do czarnego da roztworu.

Czarny włos i czarna ziemia -

żeby spełnić swe życzenia.

- Czary mary! — zakrzyknęła.

Kocioł wybuchł i zniknęła.

Grabowska-Bednarz, 2014, s. 28-29

Co sądzisz o czarnej musze? Jaka, według Ciebie, jest, co robiła? Spróbuj dokładnie to opisać.

Jak skończyła się ta historia?

Pobaw się w czarną muchę i tak jak ona spróbuj przygotować magiczny wywar. Co do niego wrzucisz i po co? Narysuj siebie w roli czarodziejki/czarodzieja.

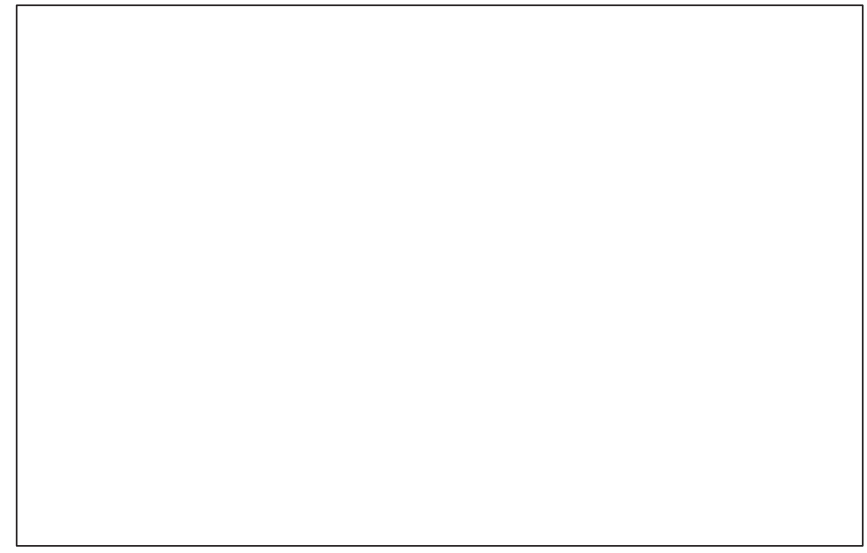

XI. Czarodziejska bajka

Dopisz (opowiedz) dalszy ciąg bajki - na pewno będzie ciekawa. W opowiadaniu użyj słów: czarodziejka (czarodziej), różdżka, pieczara i tęcza. Początek, jak to zawsze w bajkach bywa, jest następujący:

Dawno, dawno temu, za siedmioma górami, za siedmioma lasami

Był (była) sobie

Zawsze rano

wieczorem zaś

Niespodziewanie jednak

$\mathrm{W}$ bajce, jak to zawsze $\mathrm{w}$ bajce bywa, 
Od tej chwili

Bardzo lubię bajki, ale

Proszę Cię, Bajko, o niewiele, czy możesz dla mnie

Na podstawie: Minczakiewicz, 2010, s. 168-169

\section{Literatura}

Bettelheim B., 1985, Cudowne i pożyteczne. O znaczeniach $i$ wartościach baśni, Danek D., przeł., t. 1-2, Warszawa.

Bogdańska T., Olszewska G.M., 2008, Rymowanki fonologiczne do ćwiczeń słuchu fonemowego, Warszawa.

Caillois R., 1973, Żywioł i ład, Osęka A., wybór, Tatarkiewicz A., przeł., Porębski M., przedm., Warszawa.

Cieślikowski J., 1985, Wielka zabawa. Folklor dziecięcy, wyobraźnia dziecka, wiersze dla dzieci, Wrocław.

Demel G., 2008, Minimum logopedyczne nauczyciela przedszkola, Warszawa.

Grabias S., 2012, Teoria zaburzeń mowy. Perspektywy badań, typologie zaburzeń, procedury postępowania logopedycznego, w: Grabias S., Kurkowska M., red., Logopedia. Teoria zaburzeń mowy, Lublin.

Grabowska-Bednarz K., 2014, Muchy, Olszanica.

Huiznga J., 1985, Homo ludens. Zabawa jako źródło kultury, Kurecka M., Wirpsza W., przeł., Warszawa.

Kozłowska K., 2004, Logopedia bliżej dziecka, Kielce.

Krupa D., 2008, Rymowanki - utrwalanki. Materiały do ćwiczeń logopedycznych, Kraków.

Jastrzębiowska G., Pelc-Pękała O., 2003, Metodyka ogólna diagnozy i terapii logopedycznej, w: Gałkowska T., Jastrzębska G., red., Logopedia. Pytania i odpowiedzi, t. 2, Opole.

Ługowska J., 2004, Punkt widzenia w strukturze komunikatu literackiego (przeznaczonego dla młodego odbiorcy), w: Bartmiński J., Niebrzegowska-Bartmińska S., Nycz R., red., Punkt widzenia $w$ tekście i dyskursie, Lublin.

Malkiewicz M., 2007, Jarmark logopedyczny. Wybór zabaw wspomagajacych mowę przedszkolaków, Gdańsk.

Minczakiewicz E.M., 2010, Jak krok po kroku wprowadzać dzieci o specjalnych potrzebach edukacyjnych $w$ świat zabawy i nauki, Kraków.

Ostasz M., 2008, Od Konopnickiej do Kerna. Studium wiersza pajdialnego, Kraków.

Ostasz M., Michalik M., 2016, Logopedyczny wiersz pajdialny, Kraków.

Ostaszewska D., Tambor J., 2004, Fonetyka i fonologia współczesnego języka polskiego, Warszawa.

Polczyk M., 2015, Terapia logopedyczna przez zabawę, w: „Logopedia Silesiana”, Przybyla O., red., t. 4, Katowice. 
Postołowicz A., 2017, „Logopedia na Wesoło”, [Białystok], nr 3.

Sambor B., 2014, Warunki anatomiczno-czynnościowe narządów mowy studentów wyższych szkół teatralnych, w: „Logopedia Silesiana”, Przybyla O., red., t. 3, Katowice.

Sarosiek A., 2015, „Logopedia na Wesoło”, [Białystok], nr 1.

Skorek E.M., 2001, Oblicza wad wymowy, Warszawa.

Wacławek M., 2014, Indywidualizacja procesów nauczania wymowy polskiej (na przykładzie hungarofonów), w: Małocha J., red., Indywidualizacja nauczania języków obcych. Badania i krytyka, Kraków.

Wacławek M., 2007, Samogłoskowe problemy polszczyzny (emisja głosu, prawidła wymowy w świetle nauczania JPjO), w: Achtelik A., Tambor J., red., Sztuka czy rzemiosło. Nauczyć Polski i polskiego, Katowice 2007.

Wacławek M., Wtorkowska M., 2017, Szara siara? O problemie palatalności u Słoweńców uczacych się języka polskiego jako obcego, w: Kubicka E., Berend M., Ritter M., red., Nowe perspektywy w nauczaniu języka polskiego jako obcego IV, Toruń.

Maria Wacławek - doktor nauk humanistycznych w zakresie językoznawstwa; lektor języka polskiego w Katedrze Polonistyki Uniwersytetu w Lublanie (Słowenia). Jej zainteresowania naukowe koncentrują się wokół JOS i stereotypów, a także reklamy, frazeologii, reguł poprawnej wymowy oraz glottodydaktyki. Autorka artykułów naukowych, rozdziałów w książkach z wymienionej tematyki.

e-mail: waclawek.maria@gmail.com 
